agency of the Columbia Broadcasting System of America, which has a representative with the expedition giving regular talks to listeners in the United States. The signals from the expedition's transmitting station at the Bay of Whales were received in South America, relayed to New York and thence to England and several other European countries. In addition to announcements by the representative mentioned above, members of the party gave a brief account of the prevailing meteorological conditions and of the scientific work being carried out by the expedition. The average daily temperature was stated to have been between $-20^{\circ}$ and $-60^{\circ} \mathrm{C}$., while a thirteen days' blizzard had been experienced recently. Admiral Byrd's advance party is located at about 123 miles nearer the South Pole than the main base at Little America. The brief programme included a musical item by members of the expedition and concluded with the singing of the British national anthem. Although reception was marred to some extent by distortion and a fairly high noise level, this broadcasting achievement showed in an interesting manner the possibilities of modern radio communication, and demonstrated that the isolation of polar expeditions is a thing of the past.

\section{Broadcasting over Wires}

AT a meeting of the Wireless Section of the Institution of Electrical Engineers on April 11, a paper entitled "Principles of Audio-Frequency Wire Broadcasting" was read by Mr. P. P. Eckersley. It is well-known that too few wave-lengths are available for the purposes of wireless broadcasting, a limitation which makes it impossible to give all listeners both a variety of choice of programme and good quality reproduction. These limitations have stimulated an interest in alternative methods of distributing programmes to listeners, and broadcasting over wires has certain basic technical and economic advantages over wireless broadcasting. Wire-broadcasting technique has been extensively applied in Holland, where 50 per cent of the Dutch listeners have their programme service laid on to the house by a wire connexion. Relatively slight developments of the same nature have taken place so far in Great Britain, although a number of companies are in operation for the re-diffusion of the ordinary wireless programmes.

THE commonest form of such re-diffusion takes place at audio-frequencies; the ordinary wireless broadcasting programmes are picked up by a receiver located where reception conditions are favourable, and the audio-frequency output of this receiver is of sufficient strength to energise at once a thousand or more loud-speakers connected to it by a line network. It is usual to connect each subscriber by two lines to this network so that a choice of two programmes is provided. Mr. Eckersley's paper dealt with the technical problems encountered in the design and construction of such a network in order to give a good quality service. An analysis was made of the effects set up by the interaction of the reactances and resistances composing the network and the loud- speakers, and it was shown that the received level, particularly towards the ends of the lines, varies with loading and frequency. Certain generalised rules have been evolved to indicate how the distortions incidental to this form of wire-broadcasting may be minimised or even eliminated.

\section{Commercial Production of Heavy Water}

THE recently discovered 'heavy water', which has created so much interest in popular as well as scientific circles, is to be produced commercially in England. Plant has been developed at the Billingham works of Imperial Chemical Industries, Ltd., which is capable of producing a continuous supply of heavy water of approximately 30 per cent purity at the rate of $5 \mathrm{gm}$. per day, while approximately pure 'heavy water' will be produced at a somewhat later date. I.C.I. anticipate that they will be able to meet any commercial demand that may arise. Urey and Washburn, in the United States, discovered that the residual water in old electrolytic cells contained a larger proportion of heavy hydrogen than the normal. It was further found that by continued electrolysis, the concentration of the 'heavy water' was enriched, ordinary light hydrogen being given off preferentially, and 'heavy water' accumulating. This gave the key to a successful method of preparing 'heavy water' in quantity, and the electrolytic method is the one in use at Billingham. Largescale production of 'heavy water' is only possible where exceptional resources of power and raw materials exist together. At Billingham, not only ordinary hydrogen in large quantities, but also residues in which 'heavy water' has accumulated, are readily available. These resources, together with cheap power and convenient research facilities, make Billingham a logical centre for the large-scale production of the new compound. Since its discovery in the United States, its probable uses are becoming more evident, and it is eloquent testimony to the vitality of British chemical technique that in so short a space of time it should have been translated from a scientific curiosity to a marketable commodity.

\section{The 24-Hour Time System}

The British Broadcasting Corporation will adopt the 24-hour system of expressing time from April 22, when 'summer-time' commences in Great Britain. The system will be used in all announcements over the microphone, in the journals published by the Corporation and in correspondence. No statement has been made as to the duration of the trial of the system, but it will doubtless be sufficiently long for the public to become thoroughly familiar with the system and for the extent of public approval or disapproval of the system to be gauged. As already announced in Nature, the Postmaster-General will await the result of this experiment before coming to a decision on the question of the adoption of the system in the Post Office. It is proposed by the B.B.C. that a time such as $17 \mathrm{~h}$. $15 \mathrm{~m}$. shall be announced as 'Seventeen-fifteen hours'. This terminology would be inaccurate and undesirable, and it is 